\title{
ICTs for non-formal education in rural Thailand
}

\author{
Sudarat Intarat and Sumalee Chanchalor \\ King Mongkut's University of Technology, Thonburi, Thailand \\ Elizabeth Murphy \\ Independent consultant
}

\begin{abstract}
Non-formal education (NFE) has a role to play in the education of marginalised groups such as out-of-school adults. NFE is based in the discourse of lifelong learning with its agenda of economic growth and active citizenship. This discourse requires moving beyond traditional conceptualisations of primary, secondary and tertiary education to conceptualise lifelong learning as formal, non-formal and informal. Information and communication technologies (ICTs) can potentially support NFE, but not enough is known about this potential. This study investigated ICT use in NFE in rural Thailand. The study compared collaboration, content knowledge and satisfaction in a Career Education course between students learning face-to-face (F2F) versus students learning F2F with desktop computers $(\mathrm{F} 2 \mathrm{~F}+\mathrm{DT})$. We compared the same variables in an English in Daily Life course between students learning F2F versus students learning F2F with mobile phones $(\mathrm{F} 2 \mathrm{~F}+\mathrm{M})$. Comparisons of the F2F and F2F+DT modes revealed no significant difference in content knowledge, in students' perceptions of collaboration or in satisfaction. Comparison of the $\mathrm{F} 2 \mathrm{~F}$ and $\mathrm{F} 2 \mathrm{~F}+\mathrm{M}$ modes revealed content knowledge and satisfaction were higher for the $\mathrm{F} 2 \mathrm{~F}+\mathrm{M}$ mode but there was no significant difference for collaboration. Comparisons of $\mathrm{F} 2 \mathrm{~F}+\mathrm{DT}$ with $\mathrm{F} 2 \mathrm{~F}+\mathrm{M}$ revealed no significant difference for content knowledge or for satisfaction. The F2F+M mode was significantly higher for perceptions of collaboration.
\end{abstract}

\section{Introduction}

Given the recognised role of education and literacy in promoting a country's global and regional competitiveness, not to mention the overall quality of life for its people, access to education is key. In fact, education is not only key. According to Article 26 of the Universal Declaration of Human Rights, education is a right. Exercise of this right requires that education be "available, accessible, acceptable and adaptable” (United Nations Educational, Scientific and Cultural Organization [UNESCO], 2016, I 4). Yet, for a large portion of the world's population, the exercise of that right is highly problematic. As of 2015, there were 58 million children out of school around the world (UNESCO, 2015). Illiteracy is endemic worldwide and is particularly high in the Asia-Pacific region with approximately 625.4 million illiterate adults (UNESCO, 2016). Many of these individuals are often women, "youth and unschooled children of ethnic minorities and disadvantaged sections of the population who live in rural and remote areas and urban slums” (UNESCO, 2016).

Thus, this right to education might be more easily exercised depending on where one lives. Levels of educational attainment, in general, worldwide, tend to be lower in rural areas, where access to educational opportunities are often inferior to those in urban areas. Rural living is not merely characteristic of the Asia-Pacific area. In fact, as of 2007, 10 million students in the USA were attending rural schools (Johnson \& Strange, 2007). In such areas, access to quality teachers may be challenging in spite of the fact that such access represents an important determinant of participation and quality of learning (DarlingHammond, 2000; Hanushek, 2005; Organisation for Economic Co-operation and Development, 2005). Rural schools may also experience challenges accessing resources, yet as an American report noted, the need for such resources may be even higher in rural areas (Malhoit, 2005).

\section{Non-formal education}

Countries have adopted various policies and practices to improve literacy and access to education. These include providing opportunities for adults who normally do not or cannot attend regular schooling to participate in non-formal education (NFE). NFE may be defined as "any organized, systematic, educational activity carried on outside the framework of the formal system to provide selected types of learning to particular subgroups in the population, adults as well as children” (Coombs \& Ahmed, 1974, 
p. 8). NFE is intentional as well as structured with regards to supports, objectives and time learning (Yang, 2015). In contrast, informal learning refers to unstructured, often non-intentional learning, for example, from leisure activities. Both forms of learning are premised on the argument put forth by Yasunaga (2014) that schools cannot be solely responsible for ensuring universal, quality basic education. As well, both forms of learning draw on recognition of the simultaneous needs for social justice as well as economic efficiency (Werquin, 2012). Compared to formal education, NFE may involve teachers with lower qualifications and less training, a simplified curriculum, different materials and more flexible terms of attendance (Rogers, 2004).

For a history of NFE and general overview, see Yasunaga (2014), Brennan (1997), Bjornavold (2000) and Romi and Schmida (2009). The term NFE dates to 1968 (see Coombs, 1968); however, there is a renewed interest in NFE (Rogers, 2004). In general, in developing countries, there has been a revival of interest in NFE in recognition of the limited reach of formal schooling (Dighe, Hakeem, \& Shaeffer, 2009, p. 2). In Third World countries, NFE has experienced widespread growth since the 1980s (Rogers, 2004). Dighe et al. (2009, p. 2) described this growth as follows:

NFE is gaining ground in many countries in the Asia Pacific region. NFE programs are expanding even in countries with a high level of basic education coverage and these programs are making the formal system more flexible. In fact, in most countries, NFE programs are evolving into a potential mechanism for meeting the emerging educational needs of people more effectively than the formal system of education.

NFE is not only relevant in developing countries and the Asia-Pacific region but also in western, postindustrial societies. Rogers (2004) explained that the renewed interest in NFE comes from the discourse of lifelong learning with its agenda of economic growth and active citizenship. Rogers added that the focus on lifelong learning requires moving beyond the traditional conceptualisation of primary, secondary and tertiary education that occurs in schools or post-secondary institutions. Instead, lifelong learning can be conceptualised as formal, non-formal and informal.

\section{NFE in Thailand's community learning centres}

Thailand represents one country that has established policies and funding for NFE. Following the 1997 Asian economic crisis, Thailand's education system underwent reform to comply with a National Education Act, promulgated in 1999. That act made provision for lifelong forms of learning to help the country move towards a knowledge-based economy. The three forms of learning instituted as a result were formal, NFE and informal education (Khankhow, n.d.). In Thailand, NFE is the responsibility of the Office of the Non-Formal Education Commission. For an overview of NFE and informal education in Thailand, see Siltragool (2008). As of 2011, approximately 3.5 million learners were involved in NFE and informal education in Thailand (UNESCO, 2011). There is also a provision for non-formal learners to transfer credits earned in NFE between institutions (Somtrakool, 2002). NFE in Thailand takes place in community learning centres (CLCs). CLCs operate in at least 24 countries with an estimated 170,000 centres in Asia-Pacific areas, are typically locally managed and are designed to meet local needs (see UNESCO, 2013). As of 2013, in Thailand, there were 8764 CLCs. These CLCs offer training in basic, vocational and life skills as well as social and community development (see Leowarin, 2010). In Thailand, such centres provide learning opportunities largely for adults who may be out of school either because they do not have access or because they withdrew.

\section{Information and communication technologies (ICTs) and NFE}

Dighe et al. (2009) argued that NFE can play a "critical role” in the education of "marginalized groups" and that ICTs can effectively support exercise of this role (p. 2). Lizardi (2002) described ICTs including radio, television, audiotape and videotape as an efficient, cost-effective means of supporting the learning of "illiterate adults and out-of-school learners" (p. 65). In general, for the Asia-Pacific regions, ICTs "offer huge potential to stimulate and realize the human capital” (Loxley \& Julien, 2004, p. vi). ICTs can play a role in the development of nations (Judi, Amin, Zin, \& Latih, 2011) and, in countries such as China, they can foster modernisation of education (Zhuzhu \& Xin, 2010). Reliance on ICTs in rural areas can compensate for lack of access to library and learning resources and expert teachers. For example, Robinson (2008) identified the potential of distance education and ICTs to support more equitable access 
to learning opportunities and resources. In Thailand, as in the Asia-Pacific region in general, there exists a commitment to the integration of ICTs in learning. The 2015 meeting of Asia-Pacific ministers of education (see UNESCO, 2014) confirmed the need for access to ICTs in remote areas to both improve the quality of learning and meet the needs of all learners.

Despite the potential for ICTs to support NFE, it is not enough to merely use ICTs in NFE programs to make them effective (Dighe et al., 2009). Several factors can influence the success of ICT use, such as policy frameworks, technology infrastructure and support, effective planning and capacity-building, training, attitudes and expectations (Dighe et al., 2009). A study of rural women's use of ICTs in India (see Best \& Maier, 2007) found that obstacles to ICT use related to time, location and illiteracy. In Thailand, Khankhow (n.d.) identified some of the challenges to the use of ICTs in education, including lack of qualified personnel, lack of financial resources, computer viruses and unfavourable attitudes regarding ICTs. Lizardi (2002) argued that the digital divide in developing countries "prohibits the widespread implementation of new innovative uses of ICTs in NFE" (p. 66) since ICT use often relies on existing telecommunication infrastructure that may be lacking. Other barriers to ICT use in NFE include a lack of locally developed content and materials combined with the cost of equipment such as computers (Lizardi, 2002) and additional problems related to displaying local-language scripts (Farrell \& Wachholz, 2004).

\section{Collaboration, satisfaction and knowledge-building with ICTs in NFE}

NFE learners are different from formal learners and are frequently out-of-school youth and adults lacking in basic literacy skills (Farrell \& Wachholz, 2004). NFE learners may be "vulnerable to professional or social exclusion because they lack significant knowledge, skills and competencies or, more precisely, recognized knowledge, skills and competencies” (Werquin, 2010, p.11). They often represent marginalised and poor sections of society (Dighe et al., 2009). They may be individuals who have not had an opportunity to benefit from schooling, which is why NFE may be referred to as second-chance schooling (Rogers, 2004; UNESCO, 2002). As Sloep (2009) argued, these learners may have needs that are "completely alien to formal learners" (p. 65). Sloep emphasised the value of collaboration for these individuals, adding that their needs may be very different from those enrolled in formal learning contexts. In the case of NFE learners already in the workforce or wanting to enter it, collaboration can be highly relevant in terms of preparing for future workplace practices, such as "learning how to share ideas, voice opinions, work on a team, and manage projects” (Haythornthwaite, 2006, p. 10). Latchem (2014) referred to the potential importance of using ICTs for cross-cultural collaboration for capacity building in developing countries and for making effective use of knowledge and expertise. Collaboration may involve relying on peers for implicit knowledge (Nonaka \& Takeuchi, 1995). It may involve sharing goals and moving beyond interaction to create tasks or an artefact (Murphy, 2004). Collaborative communication may include both agreeing and disagreeing with others (Soller, 2001).

In addition to collaboration, satisfaction is an important factor to consider in relation to learning with ICTs not only for NFE learners but learners in general. Students' use of ICTs is partially dependent on their perceptions of its benefits (Kirkwood \& Price, 2005). Males may be more inclined to see positive benefits (Kadijevich, 2000; Li \& Kirkup, 2007). An analysis of 300 studies on learning in higher education that combined traditional face-to-face (F2F) learning with online course information identified an "overwhelmingly positive” response by students to ICTs (Sharpe, Benfield, Roberts, \& Francis, 2006, p. 3). Sun, Tsai, Finger, Chen, and Yeh (2008) studied satisfaction in e-learning, which they defined as using telecommunication technology for education and training. They found that the factors that affected learners' satisfaction were "learner computer anxiety, instructor attitude toward e-Learning, e-Learning course flexibility, e-Learning course quality, perceived usefulness, perceived ease of use, and diversity in assessments” (p. 1183). Other factors related to satisfaction include usefulness, ease of use, interaction (Arbaugh, 2000) and comfort and knowledge (Piccoli, Ahmad, \& Ives, 2001).

\section{The present study}

The potential of ICTs for NFE in rural CLCs combined with a dearth of research in this area served as the motivation for the studies reported on in this paper. The first study (study 1) was carried out in a Career Education course. The second (study 2) was carried out one semester later in an English in Daily Life course. Both courses are part of the prescribed curriculum for NFE in Thailand. Given the increased 
access to networked computers, the Internet and mobile technologies for learning, it is relevant to explore the potential of various approaches to ICT use for NFE through comparisons with F2F modes of learning. Selwyn (2003) argued that "much adult learning is perhaps best suited to a combined approach of old and new technologies and face-to-face teaching and learning” (p. 14).

To identify the value, we focused on three factors: satisfaction, collaboration and content knowledge. Specifically, the two studies compared blended and F2F modes of learning. Wu, Tennyson, and Hsia (2010) defined blended as an approach to learning that combines or blends various styles of learning and methods of delivery. The blend in the case of the two studies involved use of F2F learning with desktop computers and mobile phones connected to the Internet. Although learners in the studies made use of online resources, they did this largely in a classroom and not in an online context. This form of blended learning is unlike that typically referred to in the literature and which includes an element of online/distance learning.

The context of the studies was NFE with adolescent and adult learners in a CLC in rural Thailand. The studies involved comparisons of three forms of learning: F2F alone; F2F and desktop computer $(\mathrm{F} 2 \mathrm{~F}+\mathrm{DT})$; and $\mathrm{F} 2 \mathrm{~F}$ and mobile $(\mathrm{F} 2 \mathrm{~F}+\mathrm{M})$. The rationale for the use of mobile phones was to overcome potential digital divide issues in terms of access to equipment and the Internet. A UNESCO (2007) report on CLCs in the Asia-Pacific region highlighted a lack of basic equipment. Mobile phones represent userowned equipment that would not be dependent on CLC provided resources.

The studies’ purposes were as follows:

(1) Study 1: Compare learning F2F versus F2F+DT for:
(a) content knowledge
(b) collaboration
(c) satisfaction.

(2) Study 2: Compare learning F2F versus F2F+M for:
(a) content knowledge
(b) collaboration
(c) satisfaction.

(3) Compare results between learning F2F+DT and F2F+M.

\section{Method}

\section{Context}

Studies 1 and 2 were conducted in a CLC in a rural area 85 kilometres west of Bangkok, Thailand. The region has a population of approximately 7000 individuals. The primary source of work is in husbandry (growing vegetables and fruits) and raising animals (pigs and cattle). There are some small cottage industries (e.g., textile weaving). The research complied with the ethics requirements of the faculty in the university in which the principal investigator was enrolled. The principal investigator received permission from the CLC to conduct the research. Only those who volunteered to participate and provided consent were included in the study.

\section{Participants}

Participants for study 1 were 18 (9 for each mode of learning) NFE learners enrolled in a Career Education course. There were five males and 13 females. They ranged in age from 15 to 35, with seven participants 15-18 years old, nine aged 21-29 years and two aged 34-35. The learners attended school on Sundays and worked on the other days of the week. Most participants were farm labourers; however, there was one office worker, two store clerks, a nanny, a mechanic and a hairdresser. Because the context was NFE, regardless of age, learners were all enrolled in the same course at the same time. Participants for study 2 were 18 (9 for each mode of learning) NFE learners in an English in Daily Life course. There were nine males and nine females. They ranged in age from 14 to 37 years, with 12 participants aged 1419, four between 20 and 24, one aged 31 and another aged 37. As with participants in study 1, these learners attended the CLC on Sundays. Most worked as farm labourers; however, there was also an office worker, a welder, a clerk and three unemployed individuals. 


\section{Procedures}

The principal investigator served as the instructor for both courses with instruction on Sundays from 9 a.m. to noon. For each study, the PI randomly divided the 18 volunteer participants into two groups of nine. F2F teaching and learning in each course involved the use of worksheets, photocopied materials and textbooks. In terms of F2F learning activities, students worked in groups with the instructor as facilitator to help students find answers to questions and complete assignments and tasks. However, in the blended modes (F2F+DT and F2F+M), in addition to in-class activity, students could access resources online through search engines and use online tools such as email and social media (Line and Facebook) to share materials, questions and answers. Students could access the desktop computers in a computer lab in the CLC with Internet access provided through a dial-up connection. The speeds of the mobile phones varied depending on the individual user’s package (e.g., 64 Kbps, 128 Kbps, 384 Kbps, 512 Kbps.)

Study 1 lasted for six weeks and study 2 for four weeks because of the length of the modules used for the intervention. Before the intervention, participants completed a pretest of content knowledge (either Career Education or English in Daily Life) as well as a survey designed to assess their perspectives on collaboration. At the end of the six- and four-week intervention periods, participants completed the posttest of content knowledge, a survey of collaboration and a survey that assessed their levels of satisfaction. Table 1 summarises the steps of the studies.

Table 1

Summary of steps

\begin{tabular}{llll}
\hline Step & Purpose & Activity & Duration \\
\hline 1 & Recruit participants & Contacted CLC to select students & 1 week \\
2 & Establish groups & Grouped participants randomly & $10 \mathrm{~min}$. \\
3 & Pretest content knowledge & Pretest & $60 \mathrm{~min}$. \\
4 & Pretest collaboration & Self-report survey & $30 \mathrm{~min}$. \\
5 & Study 1 intervention & Career Education & $3 \mathrm{hrs} /$ week, 6 weeks \\
& Study 2 intervention & English in Daily Life & $3 \mathrm{hrs} /$ week, 4 weeks \\
6 & Posttest content knowledge & Posttest & $60 \mathrm{~min}$. \\
7 & Posttest collaboration & Self-report survey & $30 \mathrm{~min}$. \\
8 & Assess satisfaction & Self-report survey & $30 \mathrm{~min}$. \\
\hline
\end{tabular}

\section{Instruments}

Study 1: Pre- and posttests

For study 1, the content was related to Career Education, such as career development, creating business plans, risk management, production and service management, marketing management and business development. The content was prescribed by the curriculum established by the Thai Ministry of Education. The pre- and posttest of content consisted of 60 multiple-choice items. An example follows:

Which items are components of the production process?

(a) Capital, labor, place and management.

(b) Product, labor, place and management.

(c) Product, price, place and promotion.

(d) Product, price, distribution and promotion.

Study 2: Pre- and posttests

All instruments were administered in the Thai Language. The content is translated into English for this paper. However, in the test of English in Daily Life, the multiple-choice questions were in Thai but the choice of response was in English. For study 2, the content was related to using English in Daily Life as based on the Thai curriculum. Topics included sharing personal information, giving an opinion, expressing ideas, greeting and leave-taking and introducing oneself and others. An example follows: 
Which is not an example of a formal greeting?
(a) Hi.
(b) Hello.
(c) Good morning.
(d) How are you?

Studies 1 and 2: Pre- and posttest of collaboration

Collaboration was measured using a self-report survey. Items in the survey were compiled from Murphy (2004), Curtis and Lawson (2001) and Soller (2001). The survey used a 5-point Likert scale ranging from 5 strongly agree, to 4 agree, 3 do not know, 2 disagree and 1 strongly disagree. Participants were invited to indicate degrees of agreement or disagreement regarding the value of the medium (F2F, F2F+DT, F2F+M) for the 11 individual items listed in Table 2. The survey used the following prompt: This mode of learning is effective for ...

Table 2

Pre-post collaboration

\begin{tabular}{|c|c|c|c|c|c|c|}
\hline No. & Items & SA & $\mathbf{A}$ & DK & $\mathbf{D}$ & SD \\
\hline 1 & Sharing feedback. & & & & & \\
\hline 2 & Completing tasks together. & & & & & \\
\hline 3 & Discussing information and knowledge. & & & & & \\
\hline 4 & Solving problems together. & & & & & \\
\hline 5 & Showing respect for peers' ideas. & & & & & \\
\hline 6 & Sharing goals. & & & & & \\
\hline 7 & Giving advice \& helping. & & & & & \\
\hline 8 & Communicating with peers. & & & & & \\
\hline 9 & Communicating with instructor. & & & & & \\
\hline 10 & Agreeing or disagreeing with ideas. & & & & & \\
\hline 11 & Sharing knowledge with instructor and peers. & & & & & \\
\hline
\end{tabular}

Studies 1 and 2: Posttest of satisfaction

The satisfaction survey was designed to assess learners' satisfaction with learning F2F, F2F+DT or F2F+M. The items, as shown in Tables 3, 4 and 5, were drawn from Arbaugh (2000) and from Piccoli et al. (2001). Items assess comfort, convenience, interaction, usefulness and perceptions of having learned. These are factors that can be relevant to both F2F and ICT contexts.

\section{Data analysis}

Content knowledge, collaboration and satisfaction were calculated by non-parametric statistical tools, that is, the Mann-Whitney $U$ test to detect differences between groups that do not follow the normal distribution. The satisfaction survey used descriptive statistics to calculate items on the Likert scale.

\section{Results}

We report results for studies 1 and 2 followed by results for the comparisons between F2F+DT and F2F+M. We then present a summary of results. All groups (e.g., F2F, F2F+DT, F2F+M) consisted of nine participants each. All Mann-Whitney U test results were calculated using an alpha of .05 $(\alpha=.05)$.

\section{Study 1: F2F versus F2F+DT}

\section{Content knowledge}

We compared F2F versus F2F+DT to determine if there was a difference in content knowledge. Results of the Mann-Whitney U test revealed that the difference between the means of F2F (9.33) and F2F+DT (9.67) was not statistically significant $(Z=-.133, p=.894)$. 
Collaboration

We compared results of learners' perceptions of the effectiveness of collaboration for F2F versus F2F+DT. The difference between the means of F2F (11.56) and F2F+DT (7.44) was not statistically significant $(Z=-1.659, p=.097)$.

\section{Satisfaction}

Table 3 presents the results of the comparison of satisfaction of F2F and F2F+DT. For F2F+DT, responses were for the majority (77.77\%) at the level of strongly agree and agree. However, for F2F, satisfaction was comparatively lower at 50\%. A high percentage (42.59\%) indicated that they did not know. In relation to the item regarding the convenience of learning, three of the nine (33.3\%) F2F participants responded that they strongly disagreed. For students' perceptions of satisfaction, the difference between the means of F2F (7.83) versus F2F+DT (11.17) was not statistically significant $(Z=$ $-1.343, p=.179)$.

Table 3

Comparison of F2F and F2F+DT for satisfaction

\begin{tabular}{|c|c|c|c|c|c|c|c|c|c|c|}
\hline \multirow[t]{3}{*}{ Survey items } & \multicolumn{2}{|c|}{$\begin{array}{c}\text { Strongly } \\
\text { agree }\end{array}$} & \multicolumn{2}{|c|}{ Agree } & \multicolumn{2}{|c|}{$\begin{array}{l}\text { Do not } \\
\text { know }\end{array}$} & \multicolumn{2}{|c|}{$\begin{array}{l}\text { Strongly } \\
\text { disagree }\end{array}$} & \multicolumn{2}{|c|}{ Disagree } \\
\hline & $\mathrm{F} 2 \mathrm{~F}$ & $\begin{array}{c}\mathrm{F} 2 \mathrm{~F} \\
+\end{array}$ & $\mathrm{F} 2 \mathrm{~F}$ & $\begin{array}{c}\text { F2F } \\
+\end{array}$ & F2F & $\begin{array}{c}\text { F2F } \\
+\end{array}$ & F2F & $\begin{array}{c}\text { F2F } \\
+\end{array}$ & F2F & $\begin{array}{c}\text { F2F } \\
+\end{array}$ \\
\hline & & DT & & DT & & DT & & DT & & DT \\
\hline $\begin{array}{l}\text { 1. I was comfortable } \\
\text { learning this way. }\end{array}$ & 0 & 1 & 4 & 7 & 5 & 1 & 0 & 0 & 0 & 0 \\
\hline $\begin{array}{l}\text { 2. The learning activities } \\
\text { were useful. }\end{array}$ & 0 & 1 & 5 & 5 & 4 & 3 & 0 & 0 & 0 & 0 \\
\hline 3. The content was useful. & 0 & 1 & 5 & 5 & 4 & 3 & 0 & 0 & 0 & 0 \\
\hline 4. Learning was convenient. & 1 & 2 & 2 & 5 & 3 & 2 & 3 & 0 & 0 & 0 \\
\hline 5. I learned a lot. & 0 & 1 & 6 & 6 & 2 & 2 & 1 & 0 & 0 & 0 \\
\hline 6. I liked learning together. & 0 & 2 & 4 & 6 & 5 & 1 & 0 & 0 & 0 & 0 \\
\hline Total (\%) & 1.85 & 14.81 & 48.15 & 62.96 & 42.59 & 22.22 & 7.41 & 0 & 0 & 0 \\
\hline
\end{tabular}

\section{Study 2: F2F versus F2F+M}

Content knowledge

Results revealed that content knowledge was higher for F2F+M (13.17) than F2F (5.83). The difference in the means was statistically significant $(\mathrm{Z}=-2.941, p=.003)$.

\section{Collaboration}

A comparison of learners' perceptions of the effectiveness of collaboration for F2F (10.72) versus $\mathrm{F} 2 \mathrm{~F}+\mathrm{M}(8.28)$ revealed that the difference between the means was not statistically significant $(Z=-.975$, $p=.330)$.

\section{Satisfaction}

The comparison of perceptions of satisfaction for F2F was mostly at the level of disagree or strongly disagree (66.66\%) while $\mathrm{F} 2 \mathrm{~F}+\mathrm{M}$ was at the agree or strongly agree level (77.78\%), as shown in Table 4. Only $12.96 \%$ of the F2F students indicated that they agreed or strongly agreed with the satisfaction statements. Results of the Mann-Whitney U test revealed that the F2F+M mean was 12.11 and the F2F mean was 6.89. The difference in satisfaction between F2F+M and F2F was significant $(Z=-2.086, p=$ .037). 
Table 4

Comparison of $F 2 F$ and $F 2 F+M$ for satisfaction by percentage

\begin{tabular}{|c|c|c|c|c|c|c|c|c|c|c|}
\hline \multirow[t]{4}{*}{ Survey items } & \multicolumn{2}{|c|}{$\begin{array}{l}\text { Strongly } \\
\text { agree }\end{array}$} & \multicolumn{2}{|c|}{ Agree } & \multicolumn{2}{|c|}{$\begin{array}{l}\text { Do not } \\
\text { know }\end{array}$} & \multicolumn{2}{|c|}{$\begin{array}{l}\text { Strongly } \\
\text { disagree }\end{array}$} & \multicolumn{2}{|c|}{ Disagree } \\
\hline & F2F & $\mathrm{F} 2 \mathrm{~F}$ & F2F & F2F & F2F & F2F & F2F & $\mathrm{F} 2 \mathrm{~F}$ & $\mathrm{~F} 2 \mathrm{~F}$ & F2F \\
\hline & & + & & + & & + & & + & & + \\
\hline & & M & & M & & M & & M & & M \\
\hline $\begin{array}{l}\text { 1. I am comfortable learning } \\
\text { this way. }\end{array}$ & 0 & 0 & 1 & 7 & 1 & 1 & 7 & 1 & 0 & 0 \\
\hline $\begin{array}{l}\text { 2. I liked the learning } \\
\text { activities. }\end{array}$ & 1 & 0 & 0 & 7 & 2 & 1 & 5 & 1 & 1 & 0 \\
\hline $\begin{array}{l}\text { 3. The content was } \\
\text { appropriate. }\end{array}$ & 1 & 1 & 0 & 6 & 1 & 1 & 5 & 0 & 2 & 1 \\
\hline 4. Learning was convenient. & 0 & 3 & 1 & 5 & 2 & 0 & 6 & 0 & 0 & 1 \\
\hline 5. I learned a lot. & 0 & 0 & 2 & 8 & 2 & 0 & 5 & 1 & 0 & 0 \\
\hline 6. I liked learning together. & 1 & 0 & 0 & 5 & 3 & 3 & 5 & 0 & 0 & 1 \\
\hline Total (\%) & 5.55 & 7.41 & 7.41 & 70.37 & 20.37 & 11.11 & 61.11 & 5.55 & 5.55 & 5.55 \\
\hline
\end{tabular}

\section{Comparisons between F2F+DT versus F2F+M}

Content knowledge

The comparison of results for content knowledge for $\mathrm{F} 2 \mathrm{~F}+\mathrm{DT}$ versus $\mathrm{F} 2 \mathrm{~F}+\mathrm{M}$ showed that the difference in the means of F2F+DT (7.11) and F2F+M (11.89) was not statistically significant $(Z=-1.910, p=$ .056).

Collaboration

Results revealed a statistically significant difference in perceptions of the effectiveness of collaboration. $\mathrm{F} 2 \mathrm{~F}+\mathrm{M}(12.28)$ was higher than F2F+DT (6.72) $(Z=-2.228, p=.026)$.

Satisfaction

The comparison of satisfaction between F2F+DT and F2F+M in Table 5 shows that the F2F+M students' responses were for the majority (77.78\%) in the category of strongly agree and agree. However, 77.77\% of the F2F+DT students' responses were also in this category. Results revealed that the difference in satisfaction between F2F+DT (9.72) and F2F+M (9.28) was not statistically significant $(Z=-.182, p=$ .855).

Table 5

Comparison of $F 2 F+D T$ and $F 2 F+M$ for satisfaction by percentage

\begin{tabular}{|c|c|c|c|c|c|c|c|c|c|c|}
\hline Survey items & \multicolumn{2}{|c|}{$\begin{array}{l}\text { Strongly } \\
\text { agree }\end{array}$} & \multicolumn{2}{|c|}{ Agree } & \multicolumn{2}{|c|}{$\begin{array}{l}\text { Do not } \\
\text { know }\end{array}$} & \multicolumn{2}{|c|}{$\begin{array}{l}\text { Strongly } \\
\text { disagree }\end{array}$} & \multicolumn{2}{|c|}{ Disagree } \\
\hline & $\mathrm{F} 2 \mathrm{~F}$ & F2F & F2F & $\mathrm{F} 2 \mathrm{~F}$ & F2F & F2F & $\mathrm{F} 2 \mathrm{~F}$ & F2F & $\mathrm{F} 2 \mathrm{~F}$ & $\mathrm{~F} 2 \mathrm{~F}$ \\
\hline & + & + & + & + & + & + & + & + & + & + \\
\hline & DT & $\mathrm{M}$ & DT & $\mathrm{M}$ & DT & $\mathrm{M}$ & DT & $\mathrm{M}$ & DT & $\mathrm{M}$ \\
\hline $\begin{array}{l}\text { 1. I am comfortable } \\
\text { learning this } \\
\text { way. }\end{array}$ & 1 & 0 & 7 & 7 & 1 & 1 & 0 & 1 & 0 & 0 \\
\hline $\begin{array}{l}\text { 2. I liked the } \\
\text { learning } \\
\text { activities. }\end{array}$ & 1 & 0 & 5 & 7 & 3 & 1 & 0 & 1 & 0 & 0 \\
\hline $\begin{array}{l}\text { 3. The content was } \\
\text { appropriate. }\end{array}$ & 1 & 1 & 5 & 6 & 3 & 1 & 0 & 0 & 0 & 1 \\
\hline $\begin{array}{l}\text { 4. Learning was } \\
\text { convenient. }\end{array}$ & 2 & 3 & 5 & 5 & 2 & 0 & 0 & 0 & 0 & 1 \\
\hline 5. I learned a lot. & 1 & 0 & 6 & 8 & 2 & 0 & 0 & 1 & 0 & 0 \\
\hline $\begin{array}{l}\text { 6. I liked learning } \\
\text { together. }\end{array}$ & 2 & 0 & 6 & 5 & 1 & 3 & 0 & 0 & 0 & 1 \\
\hline Total (\%) & 14.81 & 7.41 & 62.96 & 70.37 & 22.22 & 11.11 & 0 & 5.55 & 0 & 5.55 \\
\hline
\end{tabular}


Table 6 summarises the results in terms of significance. In relation to content knowledge, the only statistically significant differences identified were for F2F+M. For content knowledge, the difference in means in favour of $\mathrm{F} 2 \mathrm{~F}+\mathrm{M}$ versus $\mathrm{F} 2 \mathrm{~F}$ was statistically significant. Regarding perceptions of collaboration, the difference between the means of F2F+M and F2F+DT was statistically significant favouring the former. For satisfaction, the mean of F2F+M was significantly higher than the mean of F2F.

Table 6

Summary of results

\begin{tabular}{llll}
\hline Mode & Content knowledge & Collaboration & Satisfaction \\
\hline F2F vs F2F+DT & No significant difference & No significant difference & No significant difference \\
F2F vs F2F+M & Significantly higher & No significant difference & Significantly higher \\
F2F+DT vs F2F+M & No significant difference & Significantly higher & No significant difference \\
\hline
\end{tabular}

\section{Discussion}

The research reported on in this paper was premised on the assumption that ICTs potentially add value to NFE. We explored that potential through comparisons of F2F learning on its own versus F2F blended with mobile phones in an English for Daily Life course and F2F blended with desktop computers in a Career Education course. We compared each group using three variables: collaboration, satisfaction and content knowledge. Results revealed significant differences only for $\mathrm{F} 2 \mathrm{~F}+\mathrm{M}$ for collaboration as compared to F2F+DT, for content knowledge as compared to the F2F group and for satisfaction as compared to the F2F group. There were no significant differences for F2F versus F2F+DT.

It is difficult to compare these results with studies of blended learning with NFE since there is such a dearth of literature in this area. In fact, the bulk of the literature is in the form of position papers, policy documents and essays (e.g., InfoDev, 2010). In general, "the evidence base for the effectiveness of ICTbased adult learning is fragmented” (Selwyn, 2003, p.7). UNESCO conducted a project that explores ICT use for NFE in CLCs entitled the Asia-Pacific Programme of Education for All (APPEAL) program (see UNESCO, n.d.). APPEAL's focus has been on the use of ICTs for access to quality education and educational resources and on community and individual empowerment. The limited findings of the APPEAL project reveal that the use of ICTs for development of local content facilitated development of basic literacy skills and allowed participants to read and write simple sentences in a short period (see UNESCO, 2005). These results, like those of this research, suggest positive outcomes for ICT use in NFE. However, the APPEAL context was different since it was a project as opposed to a study and the focus was on users developing their own content to build literacy skills.

Bonk, Olson, Wisher, and Orvis' (2002) findings revealed that learners experienced difficulties with blended learning because of access to equipment and to the Internet. Similarly, So and Brush (2008) found that low satisfaction with blended learning presented an obstacle to its adoption. Their study was not conducted in an NFE, CLC context; thus, comparisons may be difficult to make. We do not know why there was no significant difference in this study between the F2F group and the blended F2F+DT. Accessibility issues may have played a role given that the desktop computers in this study were available only in the CLC's computer lab. Additionally, and perhaps more importantly, the fact that the connections were through a telephone line may have impeded access to video and images because of the speeds required for such content. Likewise, the more positive results related to the F2F+M group may be due in part to better download speeds, access and ease of use given that students each had their own mobile phone that they could access anywhere and at any time. Access to equipment and the Internet may have played a role in the studies' results as in Bonk et al.'s (2002) study since Internet access can be less reliable in rural contexts. As Selwyn (2003) argued:

Issues of time, cost, quality of the technology, the environment in which it is used, people's experience of using ICTs, the availability of human and technological support and resources that people have available are all crucial mediating factors in people's 'access' to ICT. Thus, it must be recognised that genuinely 'universal' and 'equitable' infrastructures to allow people to use ICTs - and to use ICTs for learning - are not in place in most countries nor can they ever be. (p. 11) 
However, 78\% of respondents in the F2F+DT group expressed satisfaction with that mode of learning compared with $50 \%$ of those in the F2F group. That statistic, while not significant, points to greater satisfaction with the blended mode. We also do not know if the positive result might have worn off over time in the sense that users may have been satisfied with having a new mode of learning versus what they were accustomed to. It was beyond the scope of this study to conduct interviews with participants to gain insight into why there was not a significant difference in these two modes. For example, was their satisfaction related to the relevance of Internet access for learning English? Wu et al.'s (2010) study using factor analysis in a blended e-learning system revealed that student satisfaction was related to interaction between "cognitive, technological environment, and social environment factors” (p. 162). They concluded that increases in students' confidence and capability with blended learning environments may be accompanied by increased satisfaction. The research reported on in this paper did not use a longitudinal design. However, longitudinal studies may be appropriate in such contexts where students might become accustomed to new forms of learning.

The significant difference in favour of the $\mathrm{F} 2 \mathrm{~F}+\mathrm{M}$ group might be explained by access to mobile technologies. The defining feature of mobile phones is that learners are not required to be "at a fixed, predetermined location” and can learn "without being tied to a tightly-delimited physical location” (Wu et al., 2012, p. 818). Valk, Rashid, and Elder (2010) highlighted the value and relevance of mobile phones for developing countries because of their prevalence, their penetration rate, their versatility in terms of being able to use the radio spectrum and their usability in contexts where there is no electrical grid. Dighe et al. (2009) identified factors associated with successful ICT-supported NFE. One factor they identified is the need to promote sustainability of ICT projects in relation to their cost. The use of mobile phones and of free online content offer a means to address issues related to access to content and to sustainability. Dighe et al. remarked on the potential of Wi-Fi to address last-mile challenges to accessibility of landlines and desktop computers in poor communities. Valk et al. noted that mobile phones improved learning outcomes in Asia by improving access and promoting new forms of learning that are sensitive to diversity amongst learners. In general, mobile phones are becoming more available and less expensive (Wu et al., 2012). Figures provided by annual government surveys (see National Statistical Office, 2015) showed that Internet use was highest among urban dwellers (49\%) compared to 31\% of rural dwellers. Likewise, mobile phone use was greater in urban (85\%) than in rural (75\%) areas. Those between the ages of 15 and 24 were the highest Internet users while those aged 25-34 were the second highest group of users.

\section{Conclusion}

The extent to which ICTs can support collaboration, satisfaction and knowledge building is important to both formal education and NFE. The required investments in infrastructure combined with the time needed for learners to become accustomed to ICT tools and software means that there needs to be added value in terms of learning. Latchem (2014) argued in relation to the use of ICTs in NFE that the accessibility and growth of ICTs, in particular, mobile phones, should facilitate learning by making it both easier to access and more economical. Similarly, results of this study suggest that, for NFE in rural areas, learning supported by mobile phones may offer more potential compared to F2F and F2F+DT learning. This result should be considered in relation to the limitations of the studies reported on in this paper and in relation to implications for research, practice and policy.

\section{Limitations}

The research reported on in this paper focused on only one country and one community. The results cannot be considered representative of what might be the case in other contexts and countries. However, given the paucity of research on use of ICTs for NFE, this research has provided exploratory results that may inform future studies. In addition, reliance on self-report measures for collaboration and satisfaction require careful interpretation. Such measures offer soft data that provide insights into participants' perspectives but these may vary depending on context and on other variables. This research was not designed to investigate relationships between satisfaction and collaboration. For example, So and Brush's (2008) study conducted in a distance learning environment found that students' perceptions of collaboration were related to both social presence and satisfaction. Also, we do not know how the satisfaction of the non-ICT participants in the F2F groups attending the same CLC might have been influenced by the presence of those in the other groups who had access to these technologies. 
Furthermore, the comparison between learning F2F+DT versus learning by $\mathrm{F} 2 \mathrm{~F}+\mathrm{M}$ is different from the comparisons made within study 1 and study 2. The F2F+DT versus $\mathrm{F} 2 \mathrm{~F}+\mathrm{M}$ comparison was made across two separate groups of learners for two different courses at two different time periods. Thus, there are other moderating factors that could affect the results. It was beyond the scope of this research to control for these factors, which might include, for example, motivation. Had the comparisons been conducted within the same groups, they may have been more easily made. However, such is the challenge of conducting research in real contexts. Researchers may experience difficulties accessing research sites such as those in this context, in rural areas, and with specialised groups. Those difficulties point to the relevance of small-scale studies conducted by instructors in their own contexts or to large-scale studies that receive government support or the support of non-governmental organisations interested in community and country development. The sample sizes in our two studies were small with only nine participants in each of the four groups. Larger-scale studies in other contexts and with more participants might produce results that are incongruent with those reported here. The studies were also limited in terms of reliance on surveys and pre- and posttests. The actual and potential roles of the ICTs in supporting collaboration, satisfaction and content knowledge might be explored in more depth through other means of data collection such as interviews or observations. For example, observations might have provided insights into how, when, where and for what purposes the Internet-connected devices were used.

\section{Implications}

In terms of implications for research, follow-up studies might focus more specifically on blended F2F+M use in NFE in terms of affordances and barriers and in terms of identifying how these affordances might be scaled and sustained and how barriers might be minimised. Although there have been many studies of mobile learning (m-learning) in developing countries, little attention had been paid to m-learning in NFE. As previously indicated, NFE has an important role to play in providing education to disadvantaged and marginalised groups and, likewise, m-learning represents an affordable and accessible option for learning for such groups. It also has the potential to overcome the urban-rural digital divide (InfoDev, 2010). Distance and online learning have received considerable attention in the research literature. If, as Norberg, Dziuban, and Moskal (2011) argued, blended learning is becoming normal in higher education, what relevance does this have for NFE?

In terms of implications for practice, the growing prevalence of mobile phones that can send and receive data over the Internet offers potential solutions to the lack of learning resources that may exist for tertiary education in rural areas. M-learning offers opportunities for collaboration between learners, something that is particularly relevant for adult NFE learners who may be isolated and marginalised. Likewise, it offers potential for peer support, which may also be of relevance to NFE learners. Lai, Khaddage, and Knezek (2013, p. 415) referred to a "semiotic relationship" between formal and informal learning with a shared boundary that can be bridged by m-learning. Likewise, NFE instructors who may not be ready to incorporate m-learning into the classroom might encourage informal use of such technologies outside of class, in support of learning.

Implications for ICT policies might include subsidies for the development of mobile content for use in NFE contexts, development of strategies for mobile use and development of applications that support NFE curricula and that are delivered in the language of the user. High costs due to technological changes may threaten the sustainability of ICT initiatives (InfoDev, 2010). As an alternative to investments in desktop computers and fixed equipment, funds may be better directed to supporting users' own equipment. Most importantly, those investments in ICT should adopt a need-based approach and offer "contextual relevancy" and "flexibility in learning contents, time and place” (InfoDev, 2010, p. 5). In general, the concomitant growth, importance and prevalence of both ICTs and NFE point to a need for focused attention by governments, agencies, researchers and all those interested in building capacity in tertiary education.

\section{Acknowledgements}

The authors would like to thank the Non-Formal Education Centre, Thailand, for supporting the research. The authors also thank the reviewers for their insightful and relevant comments. 


\section{References}

Arbaugh, J. (2000). Virtual classroom characteristics and student satisfaction with internet-based MBA courses. Journal of Management Education, 24(1), 32-54. doi:10.1177/105256290002400104

Best, M., \& Maier, S. (2007). Gender, culture and ICT use in rural south India. Gender, Technology and Development, 11(2), 137-155. doi:10.1177/097185240701100201

Bjornavold, J. (2000). Making learning visible: Identification, assessment and recognition of non-formal and informal learning in Europe. Luxembourg: Office for Official Publications of the European Communities. Retrieved from http://hdl.voced.edu.au/10707/61844

Bonk, C., Olson, T., Wisher, R., \& Orvis, K. (2002). Learning from focus groups: An examination of blended learning. International Journal of E-Learning \& Distance Education, 17(3), 97-118. Retrieved from http://www.ijede.ca/index.php/jde/article/viewArticle/299http://www.ijede.ca/index.php/jde/article/

Brennan, B. (1997). Reconceptualizing non-formal education. International Journal of Lifelong Education, 16(3), 185-200. doi:10.1080/0260137970160303

Coombs, P. (1968). World educational crisis: A systems approach. New York, NY: Oxford University Press.

Coombs, P., \& Ahmed, M. (1974). Attacking rural poverty: How non-formal education can help. Baltimore, MD: John Hopkins University Press.

Curtis, D., \& Lawson, M. (2001). Exploring collaborative online learning. Journal of Asynchronous Learning Networks, 5(1), 21-34. Retrieved from sloanconsortium.org/sites/default/files/v5n1_curtis_1.pdf

Darling-Hammond, L. (2000). Teacher quality and student achievement: A review of state policy 2000. Education Policy Analysis Archives, 8. doi:/10.14507/epaa.v8n1.2000

Dighe, A., Hakeem, H., \& Shaeffer, S. (2009). ICTs in non-formal education in Asia Pacific. In S. Ahktar \& P. Arinto (Eds.), Digital review of Asia Pacific 2009-2010 (pp. 59-66).New Delhi: Sage. Retrieved from http://www.digital-review.org/uploads/files/pdf/2009-2010/4th_edition_prelim.pdf

Farrell, G., \& Wachholz, C. (2004). Integrating information and communication technologies in education in Asia and the Pacific: Trends and observations. In G. Farrell \& C. Wachholz (Eds.), Metasurvey on the use of technologies in education in Asia and the Pacific (pp. 265-72). Bangkok: UNESCO. Retrieved from http://www.unescobkk.org/fileadmin/user_upload/ict/ebooks/metasurvey/4integrating.pdf

Hanushek, E. (2005). Economic outcomes and school quality 2005. Paris \& Brussels: The International Institute for Educational Planning \& International Academy of Education. Retrieved from http://hanushek.stanford.edu/sites/default/files/publications/Hanushek 2005 IIEP EducPolSeries.pdf

Haythornthwaite, C. (2006). Facilitating collaboration in online learning. Journal of Asynchronous Learning Networks, 10(1). Retrieved from http://onlinelearningconsortium.org/jaln_full_issue/volume-10-issue-1-february-2006/

InfoDev. (2010). Information and communication technology for education in India and South Asia: Essay V ICT in non-formal education. Mumbai: PricewaterhouseCoopers. Retrieved from http://www.infodev.org/infodev-files/resource/InfodevDocuments 937.pdf

Johnson, J., \& Strange, M. (2007). Why rural matters: The realities of rural education growth. Arlington, VA: Rural School and Community Trust. Retrieved from ERIC database. (ED498859)

Judi, H., Amin, H., Zin, N., \& Latih, R. (2011). Rural students' skills and attitudes towards information and communication technology. Journal of Social Sciences, 7(4), 619-626. Retrieved from http://thescipub.com/PDF/jssp.2011.619.626.pdf

Kadijevich, D. (2000). Gender differences in computer attitude among ninth-grade students. Journal of Educational Computing Research, 22(2), 145-154. doi:10.2190/K4U2-PWQG-RE8L-UV90

Khankhow, T. (n.d.). ICT and non-formal education in Thailand. Retrieved from http://www.crnfe.ac.th/articles/ict_and_nfe_in thailand.htm

Kirkwood, A., \& Price, L. (2005). Learners and learning in the twenty-first century: What do we know about students' attitudes towards and experiences of information and communication technologies that will help us design courses? Studies in Higher Education, 30(3), 257-274. doi: $10.1080 / 03075070500095689$

Lai, K., Khaddage, F., \& Knezek, G. (2013). Blending student technology experiences in formal and informal learning. Journal of Computer Assisted Learning, 29(5), 414-425. doi:10.1111/jcal.12030

Latchem, C. (2014). Informal learning and non-formal education for development. Journal of Learning for Development, 1(1). Retrieved from http://www.jl4d.info/index.php/ejl4d/article/view/6/6 
Leowarin, S. (2010). Community learning centres in Thailand. Adult Education and Development, 74, 728. Retrieved from https://www.dvv-international.de/en/adult-education-anddevelopment/editions/aed-742010/experiences-from-asia/community-learning-centres-in-thailand/

Li, N., \& Kirkup, G. (2007). Gender and cultural differences in Internet use: A study of China and the UK. Computers \& Education, 48(2), 301-312. doi:10.1016/j.compedu.2005.01.007

Lizardi, A. (2002). ICTs and non-formal education: Technology for a brighter future. TechKnowLogia, 65-67. Retrieved from http://www.techknowlogia.org/TKL_Articles/PDF/426.pdf

Loxley, W., \& Julien, P. (2004). Information and communication technologies in education and training in Asia and the Pacific. Manila: Asian Development Bank. Retrieved from http://www.adb.org/sites/default/files/publication/28989/ict-education-training.pdf

Malhoit, G. (2005). Providing rural students with a high quality education: The rural perspective on the concept of educational adequacy. Raleigh, NC: Rural School and Community Trust. Retrieved from http://www.ruraledu.org/user_uploads/file/Providing_Rural_Students.pdf

Murphy, E. (2004). Recognizing and promoting collaboration in online asynchronous discussions. British Journal of Educational Technology, 35(4), 421-431. doi:10.1111/j.0007-1013.2004.00401.x

National Statistical Office. (2015). The 2015 household survey on the use of information and communication technology. Bangkok: Ministry of Information and Communication Technology. Retrieved from http://web.nso.go.th/en/survey/ict/data_ict/2015_establishment_Full Report.pdf

Nonaka, I., \& Takeuchi, H. (1995). The knowledge creating company: How Japanese companies create the dynamics of innovation. New York, NY: Oxford University Press.

Norberg, A., Dziuban, C., \& Moskal, P. (2011). A time-based blended learning model. On the Horizon, 19(3), 207-216. doi:10.1108/10748121111163913

Organisation for Economic Co-operation and Development. (2005). Teachers matter: Attracting, developing and retaining effective teachers. Paris: Author. Retrieved from https://www.oecd.org/edu/school/34990905.pdf

Piccoli, G., Ahmad, R., \& Ives, B. (2001). Web-based virtual learning environments: A research framework and a preliminary assessment of effectiveness in basic IT skill training. MIS Quarterly,25(4), 401-426. doi:10.2307/3250989

Robinson, B. (2008). Using distance education and ICT to improve access, equity and the quality in rural teachers' professional development in western China. The International Review of Research in Open and Distributed Learning, 9(1). doi:10.19173/irrodl.v9i1.486

Rogers, A. (2004). Looking again at non-formal and informal education: Towards a new paradigm. The Encyclopaedia of Informal Education. Retrieved from http://www.infed.org/biblio/non_formal_paradigm.htm

Romi, S., \& Schmida, M. (2009). Non-formal education: A major educational force in the postmodern era. Cambridge Journal of Education, 39(2), 257-273. doi:10.1080/03057640902904472

Selwyn, N. (2003, November). ICT in non-formal youth and adult education: Defining the territory. Paper presented at the NCAL/OECD International Roundtable, Philadelphia, PA. Retrieved from http://www.ibrarian.net/navon/paper/Thematic_Session_I.pdf?paperid=1675332

Sharpe, R., Benfield, G., Roberts, G., \& Francis, R. (2006). The undergraduate experience of blended elearning: A review of UK literature and practice. York: The Higher Education Academy. Retrieved from https://www.heacademy.ac.uk/sites/default/files/sharpe_benfield_roberts_francis_0.pdf

Siltragool, W. (2008). Non-formal education in Thailand. Country profile prepared for the Education for All Global Monitoring Report 2008 Education for All by 2015: Will we make it? Bangkok: UNESCO Asia and Pacific Regional Bureau for Education. Retrieved from http://unesdoc.unesco.org/images/0015/001555/155581e.pdf

Sloep, P. (2009). Fostering sociability in learning networks through ad-hoc transient communities. Computer-Mediated Social Networking, 53(22), 62-75. doi:10.1007/978-3-642-02276-0_7

So, H.-J, \& Brush, T. (2008). Student perceptions of collaborative learning, social presence and satisfaction in a blended learning environment: Relationships and critical factors. Computers \& Education, 51(1), 318-336. doi:10.1016/j.compedu.2007.05.009

Soller, A. (2001). Supporting social interaction in an intelligent collaborative learning system. International Journal of Artificial Intelligence in Education, 12(1), 40-62. Retrieved from http://iaied.org/pub/980/file/980_paper.pdf

Somtrakool, K. (2002). Building bridges between formal, non-formal and informal: Policies and strategies for lifelong learning in Thailand. In M. Singh (Ed.), Institutionalising lifelong learning: Creating conducive environments for adult learning in the Asian context, (pp. 111-116). Hamburg: 
UNESCO Institute for Education. Retrieved from http://www.unesco.org/educaion/uie/pdf/ILLBOOK.pdf

Sun, P., Tsai, R., Finger, G., Chen, Y., \& Yeh, D. (2008). What drives a successful e-learning? An empirical investigation of the critical factors influencing learner satisfaction. Computers \& Education, 50(4), 1183-1202. doi:10.1016/j.compedu.2006.11.007

UNESCO. (2002). Innovations in non-formal education: A review of selected initiatives from the Asia Pacific region. Bangkok: Author. Retrieved from http://unesdoc.unesco.org/images/0012/001281/128168e.pdf

UNESCO. (2005). Approaches to community-based learning using ICT shared at UNESCO workshop. New Delhi: Author. Retrieved from http://portal.unesco.org/ci/fr/ev.php-

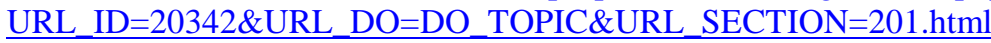

UNESCO. (2007). Strengthening community learning centres through linkages and networks: A synthesis of six country reports. Bangkok: Author. Retrieved from http://unesdoc.unesco.org/images/0015/001521/152157e.pdf

UNESCO. (2011). Non-formal and informal education. Bangkok: Author. Retrieved from http://www.unescobkk.org/education/resources/resources/education-system-profiles/thailand/nonformal-and-informal-education/

UNESCO. (2013). National qualifications frameworks for lifelong learning development: Community learning centres. Asia-Pacific Regional Conference Report 2013. Paris: Author. Retrieved from http://unesdoc.unesco.org/images/0022/002265/226538E.pdf

UNESCO. (2014). Asia-Pacific statement on education beyond 2015. Bangkok: Author. Retrieved from http://www.unescobkk.org/fileadmin/user_upload/epr/APREC/Presentations/APREC_Bangkok_State ment_Final.pdf

UNESCO. (2015). Education for all 2000-2015: Achievements and challenges. Paris: Author. Retrieved from http://unesdoc.unesco.org/images/0023/002325/232565e.pdf

UNESCO. (2016). ICT applications for non-formal education: Project description. Bangkok: Author. Retrieved from http://www.unescobkk.org/education/ict/ict-in-education-projects/non-formaleducation/ict-applications-for-non-formal-education-programmes/project-description/

UNESCO. (n.d.). ICT in education. Bangkok: Author. Retrieved from http://www.unescobkk.org/education/ict/ict-in-education-projects/non-formal-education/ictapplications-for-non-formal-education-programmes/activities/

Valk, J., Rashid, A., \& Elder, L. (2010). Using mobile phones to improve educational outcomes: An analysis of evidence from Asia. The International Review of Research in Open and Distributed Learning, 11(1). doi:10.19173/irrodl.v11i1.794

Werquin, P. (2010). Recognition of non-formal and informal learning: Country practices. Paris: Organisation for Economic Co-operation and Development. Retrieved from https://www.oecd.org/edu/skills-beyond-school/44600408.pdf

Werquin, P. (2012). Recognition of non-formal and informal learning in OECD countries: An overview of some key issues. Paris: OECD. Retrieved from http://www.die-bonn.de/doks/report/2009erwachsenenbildner-01.pdf

Wu, J., Tennyson, R., \& Hsia, T. (2010). A study of student satisfaction in a blended e-learning system environment, Computers in Education, 55(1), 155-164. doi:10.1016/j.compedu.2009.12.012

Wu, W., Wu, Y., Chen, C., Kao, H., Lin, C., \& Huang, S. (2012). Review of trends from mobile learning studies: A meta-analysis. Computers \& Education, 59(2), 817-827. doi:10.1016/j.compedu.2012.03.016

Yang, J. (2015). Recognition, validation and accreditation of non-formal and informal learning in UNESCO member states. Hamburg: UNESCO Institute for Lifelong Learning. Retrieved from http://unesdoc.unesco.org/images/0023/002326/232656e.pdf

Yasunaga, M. (2014). Non-formal education as a means to meet leaning needs of out-of-school children and adolescents. Montréal: UNESCO Institute of Statistics (UIS) and the United Nations Children's Fund (UNICEF). Retrieved from http://allinschool.org/wp-content/uploads/2015/01/OOSC-2014Non-formal-education-for-OOSC-final.pdf

Zhuzhu, W., \& Xin, L. (2010). Chinese schools modern distance education project in rural areas. British Journal of Educational Technology, 41(4), 612-613. doi:10.1111/j.1467-8535.2010.01073.x 
Corresponding author: Sudarat Intarat, sudarat.intarat@mail.kmutt.ac.th

Australasian Journal of Educational Technology (C) 2017.

Please cite as: Intarat, S., Chanchalor, S., \& Murphy, E. (2017). ICTs for non-formal education in rural Thailand. Australasian Journal of Educational Technology, 33(4), 107-121. https://doi.org/10.14742/ajet.3165 